\title{
Искуство Универзитетске библиотеке „Светозар Марковић” у успостављању Дигиталног репозиторијума Универзитета у Београду - PHAIDRA
}

\author{
Драгана Столић \\ Универзитетска библиотека „Светозар Марковић”, Београд \\ stolic@unilib.bg.ac.rs
}

\begin{abstract}
Сажетак
Први мултидисциплинарни институционални репозиторијум у Републици Србији успостављен је на Универзитету у Београду 2011. године. Одржавање и контрола његовог функционисања поверени су Универзитетској библиотеци „Светозар Марковић”, која је била координатор Темпус пројекта Нови библиотечки сервиси на универзитетима Западног Балкана у оквиру којег је покренут овај и још пет репозиторијума у региону. Као програмска основа узет је систем PHAIDRA, креиран на Универзитету у Бечу и развијен на темељу софтвера отвореног кода Fedora. У раду се даје преглед функционалности система и приказује начин његовог коришћења на универзитетима. У овом тренутку бригу о садржају репозиторијума воде универзитети, односно библиотеке (универзитетске и факултетске), док је самоархивирање заступљено знатно мање. Највећи део садржаја обухвата докторске дисертације, кроз систем Етезе, или мастер радове, које похрањују библиотекари неких факултетских библиотека. За потпун развој система потребно је, поред непрекидног техничког усавршавања и унапређивања, да га прихвате и наставници и сарадници универзитета јер је њима првенствено и намењен као алат за наставни и научни рад.
\end{abstract}

Кључне речи: институционални репозиторијуми, Универзитет у Београду, PHAIDRA, самоархивирање, дигиталне библиотеке, докторске дисертације, отворени приступ

\section{Увод}

Успостављањем Дигиталног репозиторијума Универзитета у Београду PHAIDRA 2011. године формиран је први универзитетски, институционални и мултидисциплинарни репозиторијум у Републици Србији. Репозиторијуми се у нашој земљи појављују са закашњењем у односу на исту праксу у свету, где првим може да се сматра ArXiv покренут још 1991. године, ${ }^{1}$ а овакви системи похрањивања публикација пуну глобалну експанзију доживели су у периоду од 2003. до 2004. године. ${ }^{2}$

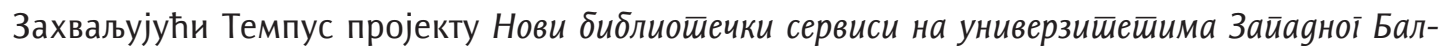
кана, који је реализован у периоду од 2010. до 2012. године, за кратко време је основано чак шест институционалних репозиторијума у региону (од тога три у Србији), што је представљало огроман напредак којим се значајно надокнадило поменуто закашњење. Истовремено, то је пред институције поставило низ задатака, искушења и изазова чије је решавање донело драгоцена искуства.

1 ArXiv, https://arxiv.org/ (preuzeto 12. 2. 2017).

Више информација о репозоторијумима могуће је прочитати у тематском броју часописа Library Technology Reports, vol. 40, 4 , нарочито текст: Susan Gibbons, "Defining an institutional repository", Library Technology Reports 40, no. 4 (2004): 6-10, http://search. ebscohost.com/login.aspx?direct=true\&db=aph\&AN=14019645\&site=ehost-live (preuzeto 10. 2. 2017). 
Формирањем репозиторијума најзад је обезбеђена адекватна инфраструктура за креирање правих електронских библиотека у којима публикације могу да буду депоноване трајно и коришћене у складу са потребама корисника који жели да дође жељеног документа, не нарушавајући права аутора. Унети објекти добијају сталну, сигурну адресу и иницијално су доступни слободном приступу, а њихов власник, као носилац ауторског права, накнадно може да одређује и уређује да ли ће бити видљиви само метаподаци или документ у целини. Власник овај статус објекта једноставно може да промени, те да га „откључа" ако за то постоје услови, пре свега правни, и тако га учини доступним свим корисницима интернета. На тај начин се поштују начела Покрета за отворени приступ (Open Access Movement) и суштински промовише овај покрет који је посвећен ширењу информација и унапређењу знања. ${ }^{3}$

\section{Пројекат и успостављање система}

Координатор пројекта Нови библиошеики сервиси била је Универзитетска библиотека „Светозар Марковић”, док су партнерске институције у региону били универзитети у Нишу, Крагујевцу, Сарајеву, Тузли, Црној Гори, а партнери из Европске уније Универзитет у Бечу (Universität Wien), Мидлсекс универзитет у Лондону (Middlesex University London) и Универзитет у Марибору (Univerza v Mariboru). Пројекат је био фокусиран на две групе активности: увођење система COBISS3, на једној, и дигиталних репозиторијума на универзитетима у региону, на другој страни: „Пројекат је намењен технолошком осавремењавању, функционалној интеграцији и институционалном ширењу академских библиотечких система у Србији, Црној Гори и Босни и Херцеговини". ${ }^{4}$

Као програмска основа репозиторијума узета је платформа развијена на Универзитету у Бечу, једном од партнера на Пројекту, која се заснива на софтверу отвореног кода Fedora. Систем PHAIDRA (Permanent Hosting, Archiving and Indexing of Digital Resources and Assets) ${ }^{5}$ креиран је у сарадњи више аустријских институција као што су Универзитетска библиотека у Бечу (Universitätsbibliothek Wien) и Рачунски центар Универзитета у Бечу, и покренут је 2006. године. Како и стоји у његовом називу, намењен је похрањивању, архивирању, индексирању и коришћењу дигиталних објеката, текстова, слика, аудио, видео материјала, линкова. Пре универзитета у Србији, био је имплементиран у институцијама у Аустрији (Аустријском научном савету - Österreichische Wissenschaftsrat, Универзитету примењених уметности у Бечу - Universität für angewandte Kunst Wien, Универзитету музичких и извођачких уметности у Грацу - Universität für Musik und darstellende Kunst Graz) и Италији (Универзитет у Падови Università di Padova).

Прва инсталација система реализована је у Универзитетској библиотеци „Светозар Марковић" у марту 2011. године, а потом и у Нишу и Крагујевцу. Универзитетска библиотека је као координатор преузела на себе улогу провајдера техничке подршке јер је сервер за сва три репозиторијума смештен у Библиотеци. ${ }^{6}$

\footnotetext{
3 Budapest Open Access Initiative, http://www.budapestopenaccessinitiative.org/read (preuzeto 18. 4. 2017).

${ }_{4}$ "New Library Services at Western Balkan Universities", http://www.westbulnet.com/AmplioCMS2/public/EnterPublic.cms2 (preuzeto 12. 2. 2017)

${ }_{5}^{5}$ Vienna University Library, Phaidra - Permanent Hosting, Archiving and Indexing of Digital Resources and Assets at the University of Vienna, http://bibliothek.univie.ac.at/english/phaidra.html (preuzeto 18. 4. 2017).

${ }^{6}$ Bogoljub Mazić, „Mreža digitalnih repozitorijuma na univerzitetima Zapadnog Balkana kao okosnica međuuniverzitetske saradnje u regiji" (rad predstavljen na 11. Međunarodna konferencija o digitalizaciji kulturne i naučne baštine, univerzitetskim repozitorijumima i učenju na daljinu, Beograd, Srbija, 30. septembar-2. oktobar, 2011).
} 


\section{Сарадња учесника у Пројекту}

Реализација пројекта овог обима, који је укључивао више партнерских институција у већем броју земаља, захтевала је добру организацију и координацију. Модел сарадње који је могао да пружи одговарајуће резултате пронађен је у посебној улози Универзитетске библиотеке у Београду, која је постала сервис другог степена важности. То је подразумевало да се сва питања, недоумице и проблеми настали у раду новоуспостављених репозиторијума упућују њој као координатору, одакле се потом обавља комуникација са Универзитетом у Бечу као сервисом највишег нивоа. ${ }^{7}$ Библиотека је, поред тога, помагала партнерским институцијама у многим додатним активностима као што су обуке о коришћењу система, припремање упутстава и сл.

Иако развијана у Бечу, PHAIDRA је остала у потпуности отворено и слободно доступно програмско решење и све допуне, надоградње или ажурирања постављени су у отворени приступ. Ипак, од партнера се очекивало да нове развојне компоненте примене сами. Најзад, сваки од партнера је могао да пружи свој допринос унапређењу система у целини и да своје иновације понуди осталима. Размена искустава и претресање текуће стратегије подразумевало је и повремена окупљања (steering committee).

Као што је и сама платформа слободно доступна, ${ }^{8}$ тако је постојала отворена могућност да се конзорцијуму PHAIDRA корисника придружи још нека институција. По завршетку Пројекта, придружио се Универзитет у Приштини (Косовска Митровица, само у сегменту подсистема Етезе, 2015), и Универзитет у Бањалуци где је у систем PHAIDRA инсталиран у целини (2016-2017).

\section{Функционалности система PHAIDRA}

Примарна намена система PHAIDRA јесте обезбеђивање инфраструктуре за похрањивање радова наставника и сарадника Универзитета, који би могли путем самоархивирања да га допуњавају, те да га користе као помоћно средство у наставном процесу. Наравно, очекивало се да ће се у великој мери користити за депоновање докторских дисертација и других завршних радова.

Систем омогућава:

1. похрањивање текстова и других дигиталних објеката (видео, аудио материјала, линкова); не допушта депоновање великог броја различитих формата, због основног становишта да се похрањују само они формати који се сматрају gуїороиним, будући да је РНАIDRA намењена ширајном чувању докумената. Могу се унети формати који се сматрају променљивим (нпр. Office), али се они уносе кроз посебну опцију. Чување докумената заснива се на стандарду Premis (Preservation Metadata: Implementation Standard);

2. описивање објеката стандардизованом схемом метаподатака коју чини LOM сет метаподатака, односно имплементирана Dublin Core схема, намењена похрањивању објеката који се користе у настави (Learning Object Metadata). Едитор метаподатака садржи велики број поља, која су подељена у једанаест целина (у последњој верзији у десет), како би се покрили сви елементи описа (порекло, детаљи о објекту и др). Број обавезних поља је релативно мали и има их укупно осам, од којих су нека већ аутоматски попуњена. Сва поља су поновљива и претражива;

\footnotetext{
Додатни опис организације сарадње видети у Dragana Stolić i dr.."Establishing Digital Repositories at Western Balkan Universities: Implementation of PHAIDRA System, Educational Activity and Regional Cooperation" (rad predstavljen na INFORUM 2012: 18th Conference on Professional Information Resources, Prague, Check Republic, May 22-24 2012), http://www. inforum. cz/pdf/2012/ stolic-dragana.pdf (preuzeto 12. 2. 2017).

8 Phaidra Api, https://github.com/phaidra/phaidra-api/wiki/Documentation (preuzeto 12. 2. 2017).
} 
3. трајни линк за сваки објекат, као стабилни URL, који је погодан за цитирање;

4. унос самосталних објеката или група објеката, кроз опције „колекција" и „контејнер”. Разлика између ових могућности лежи у томе што је колекција и сама третирана као објекат са сопственим трајним линком; она може да се допуњава или расформира. Контејнер подразумева да појединачни објекти немају свој трајни линк, већ су видљиви само у оквиру групе;

5. примену правне регулативе која је уграђена у систем (Лиценце Креативне заједнице) и омогућава једноставну заштиту докумената. Поље описа намењено питању заштите ауторског права је обавезно;

6. инкорпорирање различитих класификационих схема (EuroVoc и OCHO);

7. измену метаподатака, што може учинити власник објекта (ауторизовани корисник који га је унео), али без могућности уклањања самог објекта;

8. контролу доступности објекта, односно „закључавање” и његово поновно „откључавање". Уколико је објекат недоступан, метаподаци о њему остају видљиви. ${ }^{9}$

Све поменуте карактеристике могу се сматрати елементарним за један репозиторијум, односно стандардним функцијама које систем за похрањивање дигиталних објеката треба да има. Оно што се додатно очекује од њега јесте да буде видљив и да га идентификују претраживачи и други сервиси за индексирање.

Кључни изазов који се поставља пред репозиторијум јесте да ли ће га адекватно користити они којима је намењен, у овом случају наставници и сарадници Универзитета.

\section{Едукација о коришћењу система}

Недуго по успостављању система, започете су организоване едукације у академској средини. Први круг је обухватио библиотекаре факултетских библиотека који би требало да постану преносиоци информација до наставног особља. Библиотекари су показали висок ниво заинтересованости за рад система и за функционисање репозиторијума. Међутим, презентације на којима је требало да присуствују наставници биле су врло слабо посећене, те се убрзо са њима престало. Они међу њима који су одслушали кратку обуку о томе шта је систем и како се објекти уносе, такође су показали заинтересованост.

Врло брзо је искрсло питање коришћења Репозиторијума за депоновање завршних радова (мастер теза и др), односно разматрано је стратешко опредељење да се докторске дисертације похрањују у електронском облику. Будући да је систем PHAIDRA омогућавао и унос других материјала, а очекивало се да ће значајан део његовог садржаја обухватити дисертације, тражио се оптималан начин за приступ делу Репозиторијума у којем су депоновани ови радови.

\section{Подсистем Етезе}

Решење је пронађено у креирању подсистема Етезе који је намењен само уносу дисертација и њиховом претраживању. Реч је о бази података која садржи метаподатке и линк до дисертације, која је похрањена у систему. Етезе су повезане са узајамним каталогом (СОВІB), одакле преузимају део метаподатака и са системом PHAIDRA, у који се преноси један број података.

На тај начин се постиже циљано претраживање дела Репозиторијума, али и лакше „баратање" његовим садржајем који је могао једноставније да се прилагођава другим системима

\footnotetext{
9 Више о техничким карактеристикама у M. Hokner and P. Budroni, "Phaidra - a Repository Project of the Univerisity of Vienna", Infotheca, 12 (2011): 23-33.
} 
(метаподатке преузимају европски и интернационални портали докторских дисертација, као што су Dart Europe и Open Access Theses and Dissertations, или националног репозиторијума - Нардус). ${ }^{10}$ Пошто је реч о јединственој бази, могуће је истовремено претраживање садржаја дисертација са четири универзитета у Србији (Београд, Ниш, Крагујевац и Приштина).

\section{Коришћење и број објеката}

Сарадња на Пројекту није укинула самосталност институција које су политику коришћења система PHAIDRA одређивале према својим потребама. Универзитет у Београду није искључио могућност самоархивирања, односно право овлашћеног корисника да, пошто се пријави, унесе одређени објекат. Право на отварање шифре имају наставници и сарадници Универзитета. Истина је да је постојало и неразумевање код корисника који су се пријављивали како би могли да користе садржај, те им је објашњено шта подразумева опција неауторизованог корисника (претраживање, преузимање садржаја у слободном приступу) и ауторизованог (поред претраживања и преузимања и могућност депоновања садржаја и регулисање питања доступности).

Када је реч о садржају, односно о саставу унетих објеката, он је у случају београдске РНАIDRA-е био одређен како општом наменом Репозиторијума (алат за наставно особље), тако и одређеним конкретним потребама (за пројекат Еуропеана депоновано је више од 1000 објеката који не спадају у продукцију Универзитета).

Највећи део Репозиторијума заузимају докторске дисертације (преко 3700 докумената), док укупан број PDF докумената износи око 7500 (у овај број улазе и странице књига које су унете кроз посебну апликацију (Book importer); систем тада додељује трајни линк свакој појединачној PDF страници). Остали садржаји (видео, аудио, линкови), уношени су у много мањем, готово занемарљивом обиму.

Број отворених корисничких налога (око 150) мали је у односу на број потенцијалних корисника, што показује да циљна група није још увек препознала Репозиторијум на адекватан начин.

\section{Електронски „магацин”}

Док је Универзитетска библиотека на себе преузела дужност систематског и обавезног похрањивања докторских дисертација кроз подсистем Етезе, што је представљало логичну и природну допуну мисије коју има као депозитна за дисертације одбрањене на Универзитету у Београду, поједини факултети (Факултет спорта и физичког васпитања, Факултет безбедности) Репозиторијум користе за депоновање осталих завршних радова, пре свега мастер теза, чије је чување у штампаном облику стварало проблем њиховог смештаја. На тај начин намена Репозиторијума је, уместо коришћења у наставном процесу, преусмерена на архивирање, односно третирање система као својеврсног елекйронскої маїацина.

Такав приступ коришћењу Репозиторијума није непожељан, али јесте непотпун, јер би пуно ангажовање његових капацитета могло да буде постигнуто уколико би се користио за текући научну продукцију, или материјале намењене настави.

${ }^{10}$ НаРДуС - Национални репозиторијум дисертација у Србији, nardus.mpn.gov.rs (преузето 18. 4. 2017). 


\section{Закључак}

Непуних седам година од успостављања Репозиторијума на Универзитету у Београду стечено је вредно искуство и јасније су сагледани проблеми које једна електронска библиотека поставља пред институцију. Основни закључци истовремено указују на смернице које би требало поштовати како би се неке замке избегле и како би се овај ресурс искористио на прави начин.

Неопходна је константна, увек доступна техничка (ИТ) подршка, која ће моћи да контролише систем, али и да га развија и унапређује, па и отклања евентуалне недостатке. Постојање „електронског магацина” поставља основни захтев његовог одржавања. Институционални репозиторијуми стога и поседују кључни предуслов који гарантује одрживост система, јер иза њега стоји институција, најчешће државна, са својим техничким и људским капацитетима. С друге стране, сам квалитет ИТ подршке мора бити довољно висок како би могао да изађе у сусрет овим захтевима. Репозиторијум PHAIDRA, и поред тога што функционише, има доста простора за унапређивање и дорађивање, пре свега кроз константно ажурирање функционалности, односно за примену оних сегмената који су развијени на Универзитету у Бечу.

Садржаји свих репозиторијума, како је искуство показало, у највећем броју случајева су одређивани и стварани деловањем самих институција, тачније оним што унесу библиотекари. Реч је пре свега о докторским дисертацијама које се уносе у Универзитетској библиотеци, или мастер радовима које уносе библиотекари неких факултета. Ради се о директној институционалној контроли, односно управљању садржајем. Број самоархивираних објеката је веома мали, али ту могућност никако не треба укидати. У суштини, пракса показује да обавезност уноса (као у случају дисертација) једино гарантује попуњавање репозиторијума новим садржајима. Пошто су у овом тренутку само дисертације под режимом обавезног депоновања, тај садржај је доминантан. Права искоришћеност, у смислу укључивања радова наставника и сарадника, постигла би се обавезним депоновањем и ових садржаја, што је најзад и показало искуство свих репозиторијума у свету. Институционални репозиторијум намењен овако великој групи корисника не може на себе да преузме улогу похрањивања радова, али може да обезбеди неопходну техничку, едукативну и инструктивну подршку.

Одржавање и развој репозиторијума институције морају да препознају као стратешки циљ, будући да се ради о стандарду у библиотечком пословању, а улагања у овај сегмент требало би да буду перманентна. Најзад, потребна је и непрекидна обука корисника како би они усвојили и адекватно користили овај ресурс библиотеке.

Наведена искуства чине само пресек у развоју система, показујући да је велики корак учињен, али да има још много простора за дораду, надоградњу и даљи развој. Репозиторијуми не би требало да постану само пуке архиве за одлагање докумената, већ диманичан, интерактиван алат научног и наставног рада. Од библиотека, односно Универзитета као институционалне подршке, треба очекивати стална улагања и дефинисане дугорочне циљеве којима се излази у сусрет потребама корисника, али и пружа нови вид чувања публикација који је постао стандард на светским универзитетима.

\section{Литература и извори:}

1. ArXiv. https://arxiv.org/ (preuzeto 12. 2. 2017).

2. Budapest Open Access Initiative. http://www.budapestopenaccessinitiative.org/read (preuzeto 18. 4. 2017).

3. Gibbons, Susan. "Defining an institutional repository". Library Technology Reports 40, no. 4 (2004): 6-10. http://search.ebscohost.com/login.aspx?direct=true\&db=aph\&AN=14019645\&site=ehost-live (preuzeto 10. 2. 2017). 
4. Hokner, M. and P. Budroni. "Phaidra - a Repository Project of the Univerisity of Vienna". Infotheca 12 (2011): 23-33.

5. Mazić, B. „Mreža digitalnih repozitorijuma na univerzitetima Zapadnog Balkana kao okosnica međuuniverzitetske saradnje u regiji". Rad predstavljen na 11. Međunarodna konferencija o digitalizaciji kulturne i naučne baštine, univerzitetskim repozitorijumima i učenju na daljinu. Beograd, Srbija, 30. septembar - 2. oktobar, 2011.

6. NaRDuS - Nacionalni repozitorijum disertacija u Srbiji. nardus.mpn.gov.rs (preuzeto 18. 4. 2017).

7. "New Library Services at Western Balkan Universities". http://www.westbulnet.com/AmplioCMS2/ public/EnterPublic.cms2 (preuzeto 12. 2. 2017).

8. Phaidra Api. https://github.com/phaidra/phaidra-api/wiki/Documentation (preuzeto 12. 2. 2017).

9. Stolić, Dragana, Bogoljub Mazić i Gordana Mazić. "Establishing Digital Repositories at Western Balkan Universities: Implementation of PHAIDRA System, Educational Activity and Regional Cooperation". Rad predstavljen na INFORUM 2012: 18th Conference on Professional Information Resources, Prague, Check Republic, May 22-24 2012 http://www. inforum. cz/pdf/2012/stolic-dragana.pdf (preuzeto 12. 2. 2017).

10. Vienna University Library. Phaidra - Permanent Hosting, Archiving and Indexing of Digital Resources and Assets at the University of Vienna. http://bibliothek.univie.ac.at/english/phaidra.html (preuzeto 18. 4. 2017).

\title{
Experience of the University Library Svetozar Marković in Establishing the Digital Repository of the University in Belgrade - PHAIDRA
}

\begin{abstract}
The first multidisciplinary institutional repository in the Republic of Serbia was established at the University of Belgrade in 2011. Support and control of its functioning were entrusted to the University Library Svetozar Marković, a coordinator of the Tempus Project New Library Services at the Western Balkan Universities, within which, besides this one, five more repositories in the region were established. The program support of all the repositories is PHAIDRA, the system created at the University of Vienna based on the Fedora open source software. This paper offers a review of the system functionality and the ways of its usage at the universities. Currently, the universities and their central and branch libraries are in charge for the content of the repository, while self-archiving is much less present. The largest part of the content includes doctoral dissertations, through the Etheses submission system, as well as master theses which are being archived at some faculty libraries. Besides continuous technical upgrade and improvement, the complete system development requires its acceptance by professors and associates of the university, to whom it is primarily intended as a tool in the educational process and research.
\end{abstract}

Keywords: institutional repositories, University of Belgrade, PHAIDRA, self-archiving, digital libraries, doctoral theses, open access 